\title{
Competencies of Production in SMEs in Assembly Industries in a Digital, Volatile Business Environment
}

\author{
Maria Hulla*, Christian Ramsauer
}

\begin{abstract}
SMEs are currently confronted with major challenges such as increasing uncertainty and volatility. In order to face these challenges, agility and digitalization can be implemented. Both concepts bring about numerous opportunities and new competency requirements. Currently, there are few scientifically based, practical training courses that focus on digitization and/or agility. The aim of this paper is to provide a roadmap for the development of the training concept. In this training, participants will be able to acquire theoretical content on a learning platform in a flexible way and they will be able to apply this knowledge in a learning factory. Based on a literature overview, requirements for such a training and the necessary skills in a digital, volatile business environment will be given.
\end{abstract}

Keywords: digitalization; digital transformation; learning factories; SMEs; volatile business environment

\section{INTRODUCTION}

Volatility and uncertainty are constantly increasing challenges in today's business environment, especially for small and medium-sized enterprises (SMEs) [1]. The resulting rising dynamics consequently lead to market developments that are difficult to predict. Agility enables companies to proactively adapt to these uncertainties and react quickly to changes in order to optimize their economic situation by leveraging the entire value chain. [2]

For some years now, digitalization has been one of the most promising enablers in terms of productivity increase in the manufacturing industry. Future production systems will be characterized by small digitized, decentralized elements that act autonomously and that are thus able to control their operation according to external specifications. In this production network, products and materials will be clearly identifiable and localizable throughout their entire life cycle. [3] Not least because of this, digitalization offers numerous advantages such as higher quality, individualization of products, reduced costs and increased flexibility and agility. Digital transformation also leads to new competency requirements. These must be taken into account for a successful, agile orientation of companies in the age of Industry 4.0. [3, 4]

Training and teaching have not kept pace with the current advances in manufacturing and demands on the labour market [5]. Particularly SMEs face problems when exploiting the potentials of digitalization, such as a more agile orientation of the company, especially due to a lack of corresponding competencies within the employees $[4,6]$. Nevertheless, only a small number of practical trainings is currently available. Moreover, traditional teaching methods show limited effectiveness in terms of developing competencies of students and employees for the current, as well as future, manufacturing environments [7]. In recent years, new training and teaching concepts have evolved. These take into account the fact that manufacturing and corresponding disciplines cannot be taught only in a classroom and that industry can develop by implementing new research results into industrial operation. [8] Therefore, modern learning approaches need to train participants in a realistic manufacturing environment and leverage industrial practice by including new manufacturing technology and knowledge [9]. Learning Factories, such as the LEAD Factory of the Institute for Innovation and Industrial Management at the Graz University of Technology, offer new, practical training opportunities that can potentially be used to build up the skills of employees.

\section{THEORETICAL BASIS}

In this chapter, a theoretical basis will be given on the topics of the relevance of SMEs, digitalization and digital transformation in SMEs, agility, competencies for the digital, volatile business environment and on Learning Factories.

\subsection{Relevance of SMEs}

The European Commission defines an SME as an enterprise with fewer than 250 employees and a turnover of up to $€ 50$ million or a balance sheet total of up to $€ 43$ million [10]. Additionally, it must be a "stand-alone" company and it may not be a partner or an affiliated company [11]. In Austria, SMEs are of significant relevance as they comprise $99.6 \%$ of all enterprises in the country (about 337,000 SMEs) and 2 million people are employed in companies of this kind. [12] Austria's SMEs are responsible for more than $60 \%$ of the turnover, gross value added and investments of the marketoriented economy. In 2017, the turnover generated by SMEs was around $€ 482$ billion. [11] A similar picture can be seen in Germany, where $99.3 \%$ of all enterprises are SMEs employing $53.5 \%$ of the population [6].

SMEs are often referred to as "hidden champions" and they possess niche expertise. They mostly have smaller budgets than large companies and a more sustainable business strategy. Micro-enterprises are predominantly traditional crafts, while small and medium-sized enterprises consist mainly of manufacturing companies and IT service providers. [6] 
SMEs in particular are confronted with high volatility and uncertainty in their business environment [13]. Employees in SMEs typically perform several different and complex tasks in the course of their regular work [14]. Deficiency of skills and competencies is currently recorded in production and engineering, in the craft and technical field of production and engineering, in the craft and technical field in all sectors of the Austrian economy, but even more predominantly in SMEs [15]. Furthermore, SMEs in particular are struggling to recognize the benefits of the fourth industrial revolution and to exploit its potential [6].

\subsection{Digitalization and Digital Transformation in SMEs}

Digitalization offers a wide range of opportunities, such as shorter lead times, improved consideration of customer needs and faster innovation cycles, and this is especially the case for SMEs. It also plays a major role in identifying, but also managing volatility [2]. Digitalization has been progressing consistently in larger companies, while SMEs still have some catching up to do [16]. A study conducted in 2017 by Arthur D. Little in cooperation with the Austrian Federal Economic Chamber (WKO) found that a large proportion of the Austrian SMEs surveyed across all industries and provinces are in the "digital newcomer" or "digitally aware" category. A study conducted in 2017 also confirms this result. According to this study, $32 \%$ of SMEs are "digital latecomers" [16, 17].

In a survey of Austrian SMEs, 1,700 participants were asked "What do you think are the biggest challenges in terms of digitization? " The most common answers were the fear of unauthorized access and the lack of competent workforce (see also Fig. 1) [18].

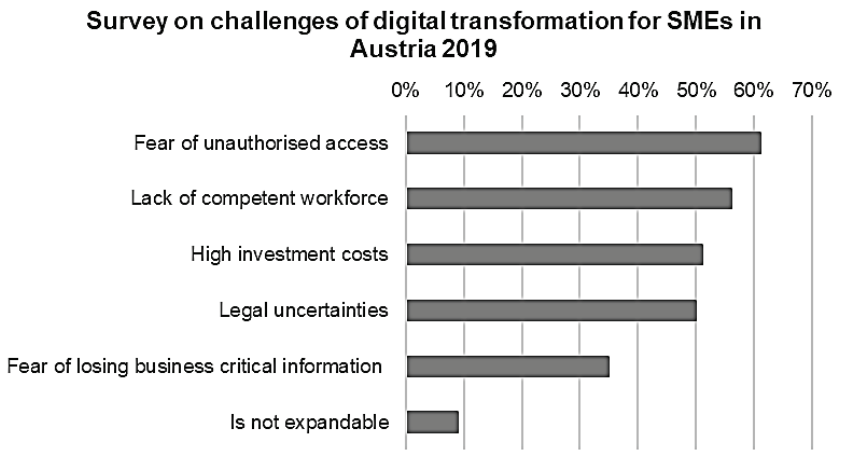

Figure 1 The challenges of digital transformation in SMEs [18].

A similar study in Germany pinpointed the adaptability of IT systems, qualification requirements for employees, the process of man-machine cooperation, work and health protection, flexibility compromises and the security of company data as the major obstacles of digital transformations in SMEs [19].

In another study, it was found that the lack of know-how and little information on digitization are the biggest challenges for SMEs [17]. To summarize, a lack of qualified people in the workforce is one of the major reasons why SMEs are still lagging behind in terms of digitalization.

\subsection{Transformability Concepts}

Due to an increasing degree of uncertainty, as well as high market volatility, producing companies need to constantly adapt to the changing environment [20]. Serious events such as the ongoing Covid-19 crisis and the financial crisis in 2008 showed how an impressive degree of global cross-linking enhances the scope and the scale of externally triggered business impacts [21]. Literature provides different concepts such as flexibility and agility as the means for facing these challenges. Nyhuis et al. define flexibility as the ability to adapt a (production) system quickly and without additional investment within a corridor defined by certain measures [22]. The term "agile" was introduced in the context of production by researchers at the Iacocca Institute in 1991 [23]. Agile production means to have "a system that is capable of operating profitably in a competitive environment of continually and unpredictably changing customer opportunities" [24]. It was defined in a similar way in 1998 by Gunasekaran who sees agility as "the capability to survive and prosper in a competitive environment of continuous and unpredictable change by reacting quickly and effectively to changing markets, driven by customerdesigned products and services" [25].

The agility of the workforce is characterized as the ability to deal with the ever-changing customer needs and uncertain scenarios, to learn from them, to generate innovative solutions and to accomplish the said goal within the stipulated time [26]. This also leads to certain requirements for the competencies of all employees in an agile organization. Accordingly, the individual person must be enabled to be agile. This requires professional skills and extra-professional skills. In the following chapter, the concept of competence is presented and consequently, the necessary competencies are discussed. [27]

\subsection{Competencies}

In order to obtain a deeper understanding of competencies, the crucial first step is to distinguish between the terms knowledge and skills. The European Parliament defines knowledge as the "outcome of the assimilation of information through learning. Knowledge is the body of facts, principles, theories and practices that is related to a field of work or study". [28] Within the European Qualifications Framework, skills are described as "cognitive (involving the use of logical, intuitive and creative thinking) or practical (involving manual dexterity and the use of methods, materials, tools and instruments) abilities" [28]. Campion et al. defined the term "competence" as "collections of knowledge, skills, abilities and other characteristics that are needed for effective performance in the jobs in question" [29]. Franz E. Weinert defines competencies as "the cognitive abilities and skills available to individuals or learnable by them to solve particular problems, as well as the associated motivational, volitional [the wilful control of actions and intentions to act] and social readiness and ability to use problem solving in variable situations successfully and responsibly" [30]. In holistic approaches, the terms 
"competency" and "competence" are used in a manner in which a difference is distinguished between them [31]. The knowledge stair was introduced by North for a better understanding of the term competency [32] (Fig. 2).

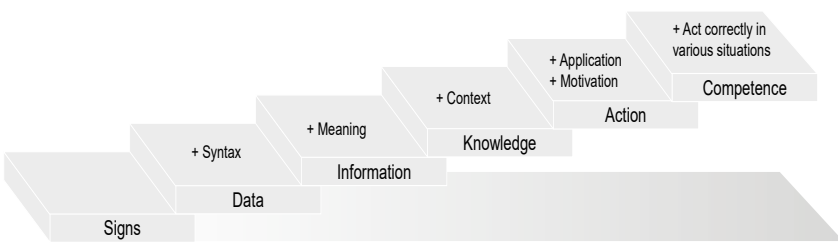

Figure 2 Knowledge stair according to North (2011) [32].

Competencies can be divided into different competency classes or models. These classes are further described in the following section.

\subsubsection{Competency Classification}

The division of competencies may vary depending on the author. A classification into three competency classes prevailed in the 1990s: professional, social and methodological competencies. This division continued until the beginning of the new millennium and was then supplemented by a fourth competency class, personal competencies proposed by Erpenbeck and von Rosenstiel, and it was slightly modified in other places. [33] Different authors further described other competency classes. An overview on the different classes is given in Fig. 3.

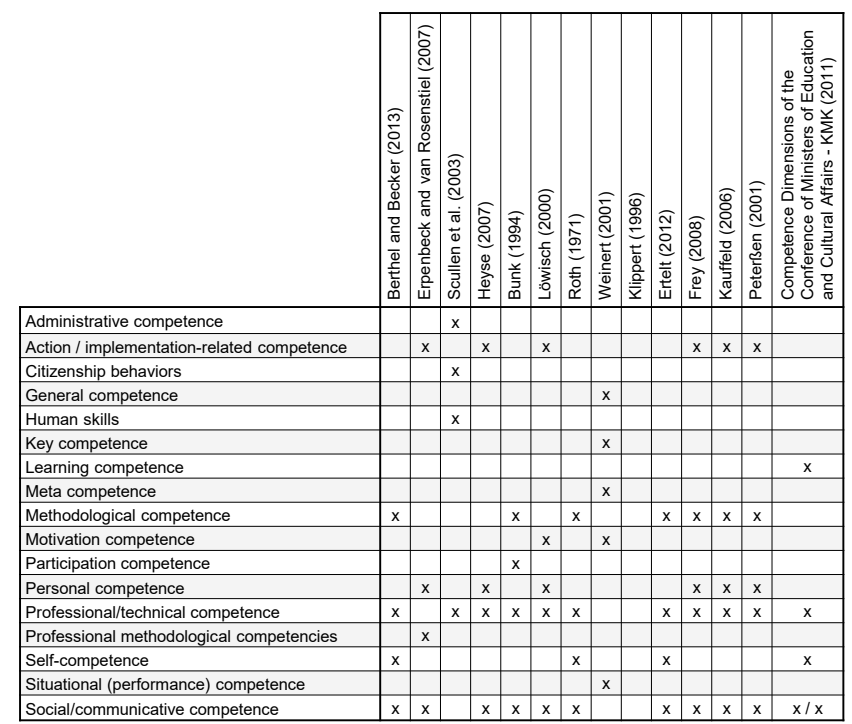

Figure 3 Competency classes (own demonstration).

For this research, the classification of Erpenbeck and van Rosenstiel will be used as it considers action- (and implementation-) related competencies and professional- and methodical-related competencies that are particularly crucial for SMEs. Competency classes divided according to these authors are described in the following section [34]:

- The personal competencies of a person refer to the individual's abilities to be aware of the consequences of their own actions, to assess themselves and to control their own actions in a creative and self-organized way. These competencies are expressed by characteristics and abilities such as flexibility, independence, ability to work under pressure or willingness to take risks.

- The social/interpersonal competencies describe the disposition of a person to self-organized action in the field of communication and cooperation.

- The action- (and implementation-) related competencies express a person's ability to act in a holistic, selforganized manner and to implement intentions.

- The ability of a person to analyse given problems and questions objectively and to solve them by using abilities, skills and knowledge is described as the professional and methodical competency. The acquisition of new methods and the creative development of the existing methods are also included.

\subsubsection{Competencies in Production in Digital Transformation}

As illustrated in Fig. 4, there are several factors leading to a change in competence profiles. In recent years, major factors for these have been digitalization, as well as globalization and shorter product life cycles. They have led to greater uncertainty levels and the need for agility [5].

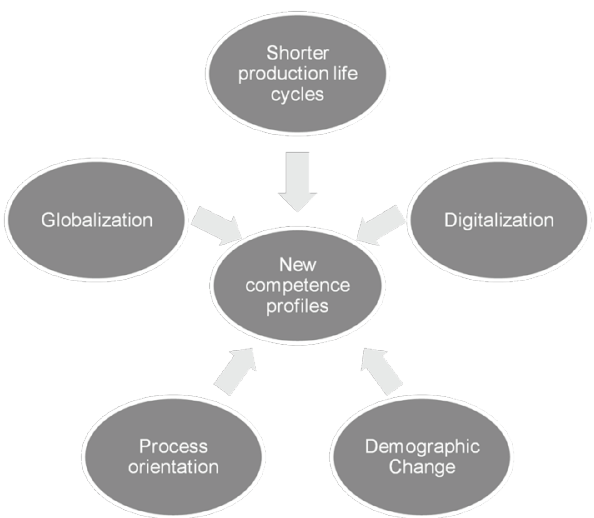

Figure 4 Changing competence profiles based on [5].

Digitalization will not only affect technology and production, but also the way we work in all its dimensions. This transformation of the work environment will change job profiles, and therefore it will require employees to be outfitted with a wide range of competencies. [5]

Personal competencies are especially important in a volatile digital business environment, since a worker's tasks will constantly change. Therefore, workers need to adapt quickly to the changing work tasks [35]. Consequently, the workforce should focus on lifelong learning and personal development [36]. Personal flexibility concerning work contents, work time and work places, as well as open mindsets, are prerequisites for agile production in order to respond quickly to market requirements and changes concerning the environment [37]. Extending beyond this creativity and high innovation capability is also very important [38]. As every individual is embedded in certain social settings such as, for example, an organization with coworkers, the ability to cooperate, communicate and to 
establish social connections is of great importance [37]. In a factory of the future, interaction takes place at various different levels, for example at a human-human and humanmachine level. Moreover, digital transformation incorporates an integration of processes in vertical and horizontal dimensions, a collaboration among standardized processes and the automation of collaboration. As a consequence, workers are responsible for a wider process scope and need to understand the relations between processes, disturbances, information and solutions. Building a network is essential to master these tasks [39]. In terms of action- (and implementation-) related competencies, it is of significant importance that ideas such as new technology solutions or new forms of collaborations are efficiently implemented on the shop floor. Complex concepts thus need to be broken down into realistic work packages and assigned to appropriate teams. [37] Another important competency is responsiveness, including capturing, recognizing and anticipating change, the immediate reaction to these changes and rapid recovery from change [27]. Professional and methodical competencies, also referred to as domain-related competencies, in the digital transformation include planning, control of production processes and networks [39]. Moreover, basic knowledge of network technologies and data processing are essential for the workers of the future. They will also need to be able to work with modern interfaces and to analyse the data by using software. [3]

\subsection{Learning Factories}

The term learning factory was first used in the USA in 2014. The number of learning factories has been constantly increasing around the world since then. [5] The learning environment of a "learning factory" is specified by [40]:

- processes that are realistic, including multiple stations, as well as organizational and technical aspects,

- a setting that can be changed and resembles a value chain,

- manufacturing of a physical product and

- a didactical concept which includes formal, informal and non-formal learning, enabled by the training participants' own actions in an on-site learning approach.

Learning factories are often miniaturized production environments close to the industrial reality. They represent models of a production system offering trainees the opportunity to implement (process) improvements and let them experience the outcomes of these changes immediately. [41]

The goal is to provide students and the industrial workforce with a close-to-industrial education environment and to let course participants experience hands-on activities though real-life projects [42]. Studies have shown that the concept of learning factories shows better performance in terms of knowledge and a capability acquisition that is better than that of traditional approaches [43]. Learning Factories follow the concept of action-oriented and experiential learning. For competency development, the assimilation of information follows first, where contents such as methods and technologies are theoretically explained and applied, and then applied and tested in the Learning Factory. In the second step, the experiential learning phase takes place where the application is experienced and seen as the basis of theoretical understanding [5].

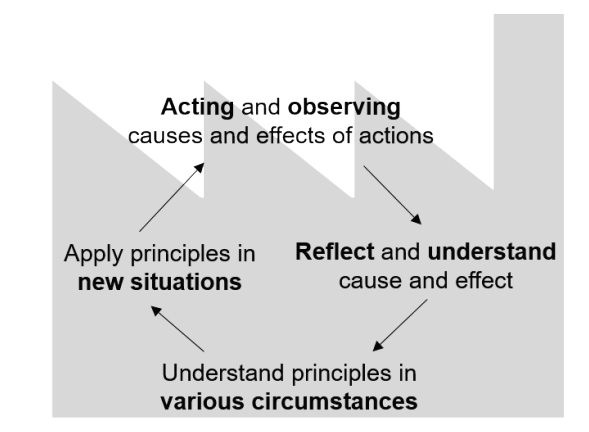

Figure 5 Training circle in Learning Factories based on [5]

The learning factory used for this research is termed the LEAD Factory and is operated by the Institute of Innovation and Industrial Management of the Graz University of Technology. It represents a manufacturing site where a 60 part scooter is assembled.

\section{GOALS AND RESEARCH QUESTIONS}

Based on the initial situation, the overall goals of the research are:

1) to highlight the challenges SMEs face in today's volatile digital business environment;

2) to determine which competencies will be required of the (production) workforce in the future;

3) to evaluate how these competencies can be taught and

4) to design and test training courses on the derived learning objectives including the current challenges of SMEs.

The first two goals are tackled in this paper. From these questions, the following research questions can be derived:

Which are the relevant competencies workers need in a volatile and digitalized environment in SMEs in the assembly industry?

\section{METHODOLOGY}

In this chapter, the methodology is described. First, the overall research framework of how to reach all four goals as it has been mentioned in Chapter 3 is tackled. The literature research will then be described.

\subsection{Overall Methodology}

In the introductory research phase, a (literature) overview is first created. The research perspective will be considered in the form of scientific journals and books. The industry perspective will be taken into account by means of the latest studies and industry insights from stakeholders, consulting firms and other stakeholders. In this phase, the 
research gap is identified and the requirements of training will be defined. In the conceptual research phase, a detailed literature study will be conducted (see Chapter 4.1) and semistructured interviews with 10-12 industry representatives of SMEs in the manufacturing industry will be conducted. The interviews will be analysed with MAXQDA, a software (tool) for a qualitative and mixed methods data analysis, and they will be interpreted for the following research phase. The descriptive phase includes the development, testing, implementation and analysis of a questionnaire. This survey will be conducted according to Forza (2016) [44]. The results of this phase will be used to create training modules based on the results of the descriptive phase by means of didactic transformation. The end-product of the research consists of training modules, which are tested and evaluated. An overview of the research is shown in Fig. 6.

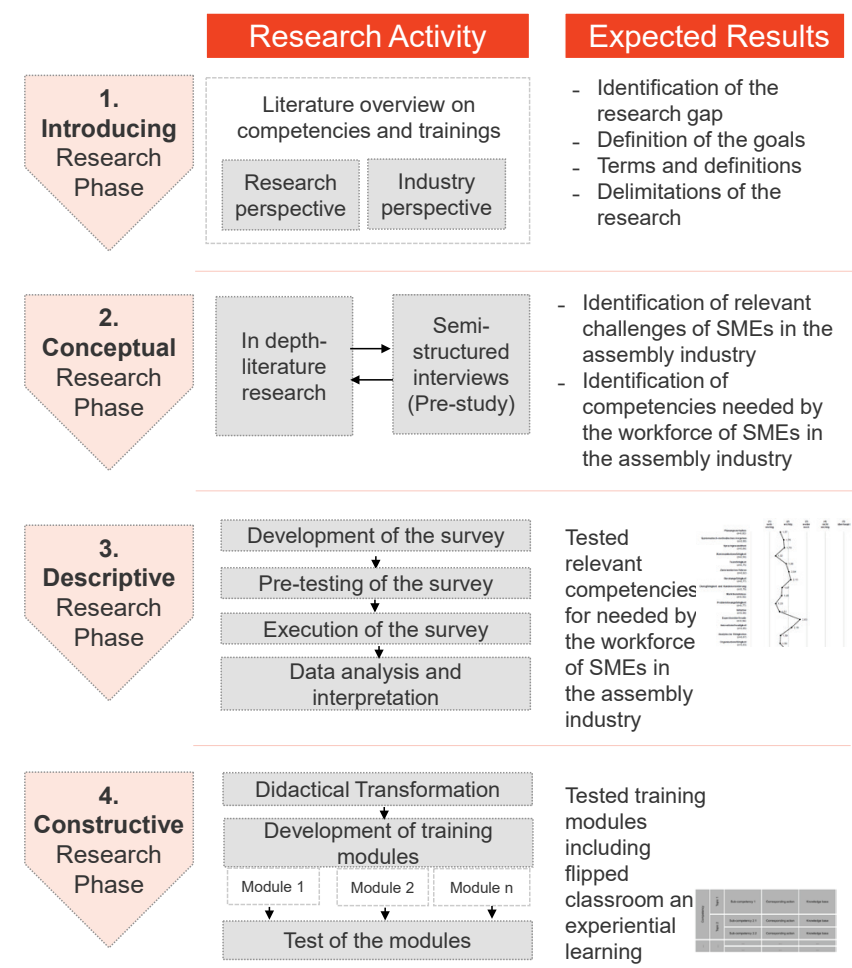

Figure 6 Overall Research Methodology based on [44, 45, 46, 47, 48].

\subsection{Literature Research}

In the first and second research phase, a literature research is conducted. While in the introducing research phase, an overview of only the current research and industry insights is created, and an in-depth literature research is performed in the second phase. The literature search is performed according to von Brocke et al. (2009) [49].

For the selection of the studies, the following process, excluding the forward and backward search, was performed (Fig. 7). After the selection of relevant articles, literature is analysed according to Webster and Watson (2002) [51].

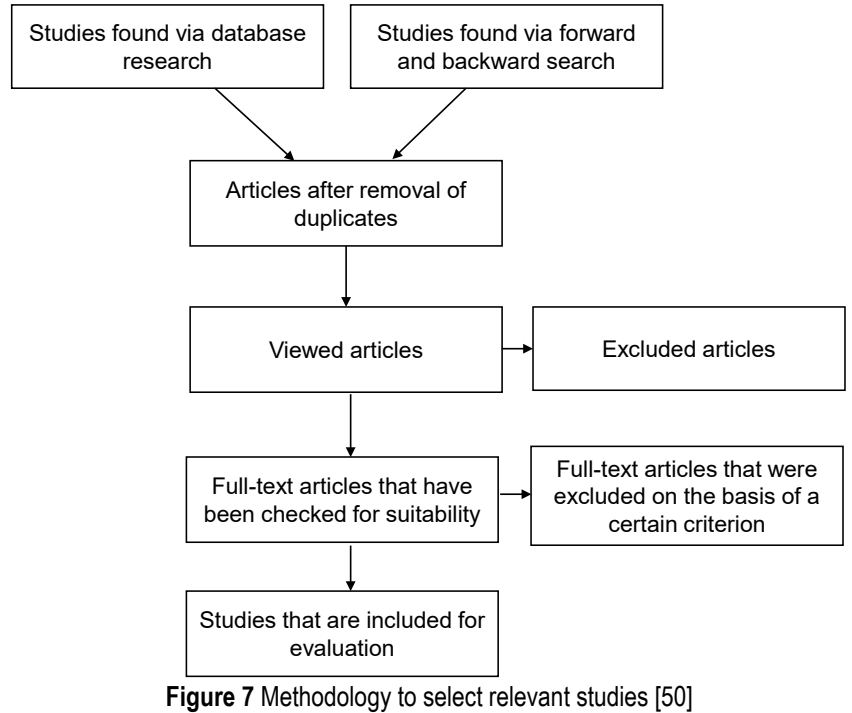

\section{RESULTS}

\subsection{Requirements for Trainings}

Based on an extensive literature search on topic challenges in SMEs, trainings for digital transformation and transformation concepts, as well as competencies and competence development, the following requirements for trainings in a volatile digital environment were derived:

Competency-oriented. The training modules need to be competency-oriented, meaning that there needs to be a structured approach for training, and an assessment that is designed for a specific outcome. The training should assist individuals to acquire certain specific competencies, in order to ensure that they are able to perform tasks to a specified standard under certain conditions. This means that the learning objectives need to be defined very clearly before the training starts. The main organizational aim is then to generate competency models for the defined functional roles that contribute to company-wide strategic goals. Competency models are defined as a set of typically between ten and thirty competencies that define the capabilities of successful performers [52].

Maturity-based. When looking at the digitalization of companies, it is not enough to focus on technological aspects only. Taking the organizational and cultural aspects into consideration, as well as the knowledge and skills of employees, are of far greater importance. Modern technologies make it possible to build a database using this input. However, it must also be possible for the organization and its actors to make good use of it in order to achieve the overall goal of adapting the company to the changing conditions. Maturity models such as the acatech Industry 4.0 Maturity Index serve as a step-by-step guide for the required developments. These maturity models include all relevant aspects for the transformation and help to determine which competencies are still lacking for the task of successfully introducing digitalization.

Flexibility and changeability concepts. Numerous changeability concepts such as workforce agility and multiskilled workforce have been developed during the past years. 
In scientific articles, it has been demonstrated that concepts such as an agile workforce contribute significantly to achieving agility throughout the entire organization [53]. For this reason, it is important to further examine the competencies needed for these concepts and to incorporate them in the training.

Multiple-case scenarios. As training should also deal with volatility and uncertainty leading to unpredictable situations, it is important to include different scenarios in the learning environment.

Incorporation of main technologies. As the main value, and thus the potentials of digitalization incorporate the use of digital technologies, it is crucial to include these technologies in training.

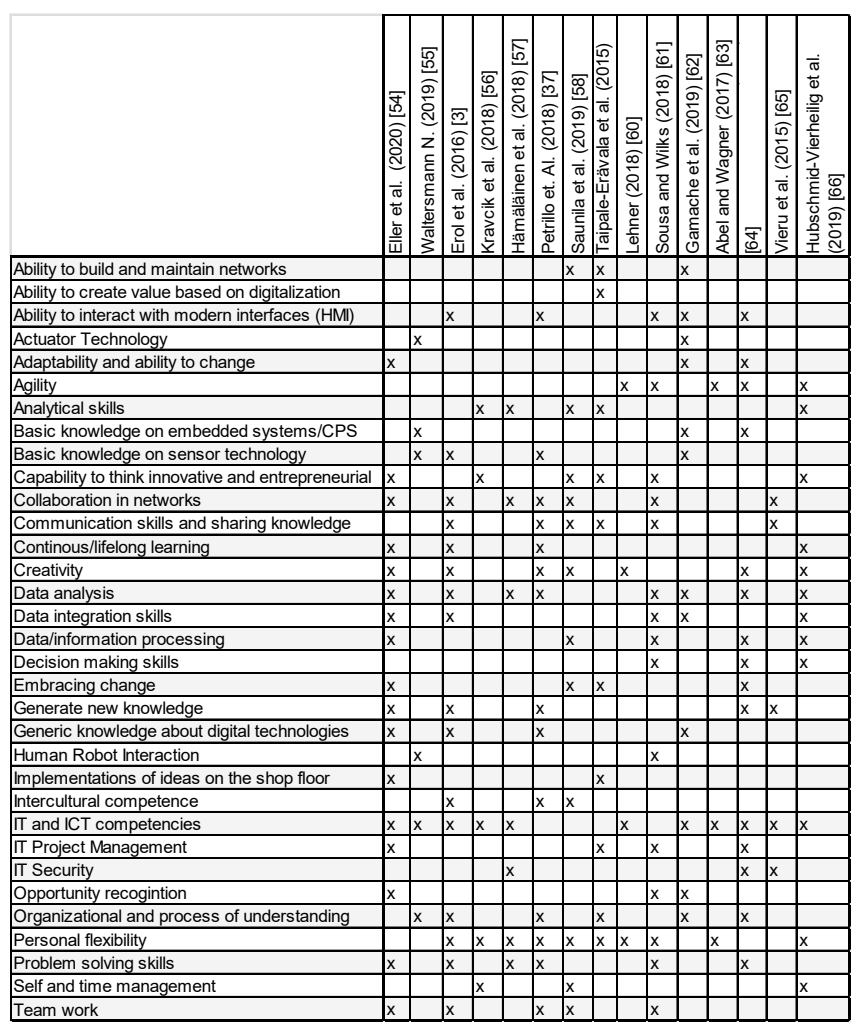

Figure 8 Competencies in SMEs for digitalization.

\subsection{Literature Research on the Competencies in SMEs}

The literature research was carried out between April and May 2020 and Google Scholar, Scopus, ScienceDirect and TU Graz Digilib were used. Studies that were published between 2014 and 2020 were incorporated. The languages of the articles were German and English. The search was focused on the following keywords: sme OR "Small and Medium sized enterprises") AND (competenc* OR skill) AND (digitization OR digitalization OR "digital Transformation" OR "Industry 4.0". Fifteen most promising articles were further analysed. Fig. 8 shows the results of the research.

When making a count of the individual competences referred to in the literature, the following were found to be the most frequently mentioned: IT and ICT competencies, personal flexibility, creativity, ability in collaboration and organization and also the process of understanding in networks.

\section{CONCLUSION}

SMES are currently facing challenges such as volatility and uncertainty. The concept of agility and digitalization are promising enablers to overcome these challenges. Nevertheless, SMEs are still struggling to transform themselves into digital enterprises and to exploit the potentials of digitalization. Furthermore, only very few (practical) training opportunities exist at the present time that incorporate changeability concepts and/or digitalization. For this reason, the authors aim to explore the competencies needed in SMEs in a digitally volatile business environment and hence, to further develop training.

In this research, an extensive literature research was carried out by focusing on the competencies and the training requirements of SMEs. It was found that the most frequently mentioned are the following: IT and ICT competencies, personal flexibility, creativity, ability in collaboration and organization and also the process of understanding in networks.

In the context of a literature research, a forward and backward search according to Watson and Webster can also be performed in order to uncover and find an even broader range of relevant articles. This study is part of a research project. The next steps are to evaluate the most important challenges of SMEs and, furthermore, to gain deeper insights into the changeability concepts of the workforce. In the conceptual research phase, interviews will be carried out with representatives of SMEs and this task will be followed by a survey.

\section{Acknowledgement}

This research was conducted within the "Voladigital" project funded by the Styrian "Zukunftsfond" and the "Land Steiermark" funding agency.

\section{Notice}

The paper will be presented at MOTSP 2020 International Conference Management of Technology - Step to Sustainable Production, which will take place from $30^{\text {th }}$ September $-2^{\text {nd }}$ October 2020 in Bol, island Brač (Croatia). The paper will not be published anywhere else.

\section{REFERENCES}

[1] Würzburger, T. (2019). Die Agilitäts-Falle: wie Sie in der digitalen Transformation stabil arbeiten und leben können. Vahlen. https://doi.org/10.15358/9783800659289

[2] Ramsauer, C., Kayser, D., \& Schmitz C. (2017). Erfolgsfaktor Agilität. Weinheim. Wiley VCH.

[3] Erol, S., Jäger, A., Hold, P., Ott, K., \& Sihn, W. (2016). Tangible Industry 4.0: a scenario-based approach to learning for the future of production. Procedia CiRp, 54(1), 13-18. https://doi.org/10.1016/j.procir.2016.03.162 
[4] Lanza, G., Nyhuis, P., Fisel, J., Jacob, A., \& Nielsen, L. (2018). Wandlungsfähige menschzentrierte Strukturen in Fabriken und Netzwerken der Industrie 4.0. (acatech Studie) München. Herbert Utz Verlage.

[5] Abele, E., Chryssolouris, G., Sihn, W., Metternich, J., ElMaraghy, H., Seliger, G., \& Seifermann, S. (2017). Learning factories for future oriented research and education in manufacturing. CIRP annals, 66(2), 803-826.

https://doi.org/10.1016/j.cirp.2017.05.005

[6] Lindner D. (2018). KMU im Digitalen Wandel - Ergebnisse empirischer Studien zu Arbeit, Führung und Organisation, Berlin Heidelberg. Springer. https://doi.org/10.1007/978-3-658-24399-9

[7] Cachay, J., Wennemer, J., Abele, E., \& Tenberg, R. (2012). Study on action-oriented learning with a Learning Factory approach. Procedia-Social and Behavioral Sciences, 55, 11441153. https://doi.org/10.1016/j.sbspro.2012.09.608

[8] Rentzos, L., Doukas, M., Mavrikios, D., Mourtzis, D., \& Chryssolouris, G. (2014). Integrating manufacturing education with industrial practice using teaching factory paradigm: A construction equipment application. Procedia CiRP, 17, 189194. https://doi.org/10.1016/j.procir.2014.01.126

[9] Deloitte (2016). Global Manufacturing Competitiveness Index. http://www2.deloitte.com/content/dam/Deloitte/global/Docum ents/Manufacturing/gx-global-mfg-competitiveness-index2016.pdf (accessed on 09.04.2020).

[10] Europäische Kommission (2015). Benutzerleitfaden zur Definition von KMU, Europäische Kommission.

[11] Bundesministerium Digitales und Wirtschaftsstandort (2020). KMU im Fokus 2019, Bericht über die Situation und Entwicklung kleiner und mittlerer Unternehmen der österreichischen Wirtschaft. Wien. BMDW.

[12] KMU Forschung (2019). https://www.kmuforschung.ac.at /zahlen-fakten/kmu-daten/https://www.bmdw.gv.at/Services /Zahlen-Daten-Fakten/KMU-FactsandFeatures.html (accessed on 14.04.2020).

[13] Mack, O., Khare, A., Krämer, A., \& Burgartz, T. (Eds.). (2015). Managing in a VUCA World. Springer. https://doi.org/10.1007/978-3-319-16889-0

[14] Schuh, G., Anderl, R., Gausemeier, J., ten Hompel, M., \& Wahlster, W. (2019). Industrie 4.0 Maturity Index - Managing the digital transformation of companies, Munich, acatech Study.

[15] Hölzl W., Bärenthaler-Sieber S., Bock-Schappelwein J., \& Friesenbuchler L. (2019). Digitalization in Austria - State of Play and Reform Needs, Wifo Institute.

[16] Arthur D. Little (2017). https://www.wko.at/branchen /stmk/information-consulting/unternehmensberatungbuchhaltung-informationstechnologie/digitale-transformationkmu.pdf (accessed on 05.05.2020).

[17] Zimmermann V. (2017). https://www.kfw.de/PDF/DownloadCenter/Konzernthemen/Research/PDF-Dokumente-Unternehmensbefragung/Unternehmensbefragung-2017-\%E2\%80\%93Digitalisierung.pdf (accessed on 05.05.2020).

[18] Statista (2019). https://de.statista.com/statistik/daten/studie /1086132/umfrage/umfrage-zu-herausforderungen-der-dig italen-transformation-fuer-kmu-in-oesterreich/ (accessed on 05.05.2020).

[19] Ludwig, T., Kotthaus, C., Stein, M., Durt, H., Kurz, C., Wenz, J., Doublet, T., Becker, M., Pipek, V., \& Wulf, V. (2016). Arbeiten im Mittelstand 4.0 - KMU im Spannungsfeld des digitalen Wandels. HMD Praxis Der Wirtschaftsinformatik, 53(1), 71-86. https://doi.org/10.1365/s40702-015-0200-y

[20] Abele, E. \& Reinhart, G. (2011). Zukunft der Produktion, München. Hanser Verlag. https://doi.org/10.3139/9783446428058
[21] Dobbs, R., Manyika, J., \& Woetzel, J. (2016). No ordinary disruption: The four global forces breaking all the trends. PublicAffairs.

[22] Nyhuis, P., Heins, M., Pachow-Frauenhofer, J., Reinhart, G., v. Bredow, M., Krebs, P., \& Wörn, A. (2008). Wandlungsfähige Produktionssysteme-Fit sein für die Produktion von morgen. ZWF Zeitschrift für wirtschaftlichen Fabrikbetrieb, 103(5), 333-337. https://doi.org/10.3139/104.101285

[23] DeVor, R., Graves, R. \& Mills, J. J. (1997). Agile manufacturing research. Accomplishments and opportunities. IIE transactions, 29(10), 813-823. https://doi.org/10.1080/07408179708966404

[24] Goldman, S. L., Nagel, R. N., \& Preiss, K. (1995). Agile competitors and virtual organizations. Strategies for enriching the customer. New York. Van Nostrand Reinhold.

[25] Gunasekaran, A. (1998). Agile manufacturing: enablers and an implementation framework. International journal of production research, 36(5), 1223-1247. https://doi.org/10.1080/002075498193291

[26] Patil, M. \& Suresh, M. (2017). Modelling the Enablers of Workforce Agility in IoT Project, A TISM Approach. Global Journal of Flexible System Management, 20(20), 157-175. https://doi.org/10.1007/s40171-019-00208-7

[27] Werther, S. \& Bruckner, L. (2018). Arbeit 4.0 Aktiv gestaltenDie Zukunft der Arbeit zwischen Agilität, People Analytics und Digitalisierung. Berlin. Springer. https://doi.org/10.1007/978-3-662-53885-2

[28] European Commission (2006). Implementing the Community Lisbon Programme: Proposal for a RECOMMENDATION OF THE EUROPEAN PARLIAMENT AND OF THE COUNCIL on the establishment of the European Qualifications Framework for Lifelong Learning. Brussels. European Commission.

[29] Campion M., Fink A., \& Ruggeberg B. (2011). Doing Competeniceis Well: Best Practices in Competency Modeling. Personnel Psychology, 64(1), 225-262 https://doi.org/10.1111/j.1744-6570.2010.01207.x

[30] Weinert F. (2014). Leistungsmessungen in Schulen, $3^{\text {rd }}$ Edition, Beltz.

[31] Teodorescu T. (2006). Competence Versus Competency: What is the Difference? Performance Improvement, 45(10), 27-30. https://doi.org/10.1002/pfi.4930451027

[32] North, K. (2011). Wissensorientierte Unternehmensführung Wertschöpfung durch Wissen, Berlin, Springer.

[33] Baumann, E. (2015). Kompetenzmanagement: moderne Methoden von Kompetenzmanagement und-messung im Unternehmen. diplom. de.

[34] Erpenbeck, J., Rosenstiel, L., Grote, S., \& Sauter, W. (2017). Handbuch Kompetenzmessung: Erkennen, verstehen und bewerten von Kompetenzen in der betrieblichen, pädagogischen und psychologischen Praxis. SchäfferPoeschel. https://doi.org/10.34156/9783791035123

[35] Lanza, G., Haefner B., \& Kaemer A. (2015). Optimization for selevtive assembly and adaptive manufacturing by means of cyber-physical system based machining. CIRP Annuals Manufacturing Technology, 64(1), 399-402. https://doi.org/10.1016/j.cirp.2015.04.123

[36] Monostori, L. (2014). Cyber-physical production systems: Roots, expectations and R\&D challenges. Procedia Cirp, 17, 9-13. https://doi.org/10.1016/j.procir.2014.03.115

[37] Petrillo, A., Cioffi, R., \& De Felice, F. (Eds.). (2018). Digital Transformation in Smart Manufacturing. BoD-Books on Demand. https://doi.org/10.5772/intechopen.69336

[38] Sharifi, H. \& Zhang, Z. (1999). A methodology for achieving agility in manufacturing organisations: An introduction. International journal of production economics, 62(1-2), 7-22. https://doi.org/10.1016/S0925-5273(98)00217-5 
[39] Gao, R., Wang, L., Teti, R., Dornfeld, D., Kumara, S., Mori, M., \& Helu, M. (2015). Cloud-enabled prognosis for manufacturing. CIRP annals, 64(2), 749-772. https://doi.org/10.1016/j.cirp.2015.05.011

[40] Abele E., Metternich J., Tisch M., Chryssolouris G., Sihn W., ElMaraghy H., Hummel V., \& Ranz F. (2015). Learning Factories for Research, Education and Training. Procedia CIRP, (15), 1-6. https://doi.org/10.1016/j.procir.2015.02.187

[41] Lamancusa, J. \& Simpson, T. (2018). The Learning Factory 10 Years of Impact at Penn State University.

[42] Enke, J., Tisch, M., \& Metternich, J. (2016). Learning factory requirements analysis - Requirements of learning factory stakeholders on learning factories. Procedia CIRP, 55, 224229. https://doi.org/10.1016/j.procir.2016.07.026

[43] Cachay, J. \& Abele, E. (2012). Developing competencies for continuous improvement processes on the shop floor through learning factories-conceptual design and empirical validation. Procedia CiRP, 3, 638-643. https://doi.org/10.1016/j.procir.2012.07.109

[44] Forza, C. (2016). Surveys, Karlsson, C. (Ed.) Research Methods for Operations Management, Second Edition. London and New York, Routledge (Taylor \& Francis Group).

[45] Thomas, S. \& Friedli, T. (2013). Produktionsnetzwerksysteme - Ein Weg zu effizienteren Produktionsnetzwerken, Dissertation, St. Gallen.

[46] Gassmann, O. (1999). Praxisnähe mit Fallstudien-forschung: Nutzen für das Technologiemanagement ist gegeben. Wissenschaftsmanagement, 5(3), S. 11-16.

[47] Kubicek, H. (1977). Heuristische Bezugsrahmen und heuristisch angelegte Forschungsdesigns als Elemente einer Konstruktionsstrategie empirischer Forschung. Köhler, Richard (Ed.): Empirische und handlungstheoretische Forschungskonzeptionen in der Betriebswirtschaftslehre, Stuttgart. 3-36.

[48] Tomczak, T. (1992). Forschungsmethoden in der Marketingwissenschaft: Ein Plädoyer für den qualitativen Forschungsansatz. Marketing Zeitschrift für Forschung und Praxis, 14(2), 77-87. https://doi.org/10.15358/0344-1369-1992-2-77

[49] Brocke, J. V., Simons, A., Niehaves, B., Niehaves, B., Reimer, K., Plattfaut, R., \& Cleven, A. (2009). Reconstructing the giant: On the importance of rigour in documenting the literature search process. ECIS. 2206-2217.

[50] Stewart, L. A., Clarke, M., Rovers, M., Riley, R. D., Simmonds, M., Stewart, G., \& Tierney, J. F. (2015). Preferred reporting items for a systematic review and meta-analysis of individual participant data: the PRISMA-IPD statement. Jama, 313(16), 1657-1665. https://doi.org/10.1001/jama.2015.3656

[51] Webster, J. \& Watson, R. T. (2002). Analyzing the past to prepare for the future: Writing a Literature Review. MIS Quarterly, 2. 13-23.

[52] Rothwell, W. J., Graber, J. M., \& Graber, J. M. (2010). Competency-based training basics. American Society for Training and Development.

[53] Breu, K., Hemingway, C. J., Strathern, M., \& Bridger, D. (2002). Workforce agility: the new employee strategy for the knowledge economy. Journal of Information technology, 17(1), 21-31. https://doi.org/10.1080/02683960110132070

[54] Eller, R., Alford, P., Kallmünzer, A., \& Peters, M. (2020). Antecedents, consequences, and challenges of small and medium-sized enterprise digitalization. Journal of Business Research, 112, 119-127. https://doi.org/10.1016/j.jbusres.2020.03.004

[55] Waltersmann, L., Luckert, M., Görzig, D., Siegert, J., \& Bauernhansl, T. (2019, November). Aligning Academic Knowledge and Industrial Needs to Enable Efficient Research Transfer in the Context of Digitization. In 2019 IEEE $11^{\text {th }}$
International Conference on Engineering Education (ICEED) (pp. 164-169). IEEE. https://doi.org/10.1109/ICEED47294.2019.8994927

[56] Kravcik, M., Wang, X., Ullrich, C., \& Igel, C. (2018, June). Towards competence development for industry 4.0. In International Conference on Artificial Intelligence in Education (pp. 442-446). Springer, Cham. https://doi.org/10.1007/978-3-319-93846-2_83

[57] Hämäläinen, R., Lanz, M., \& Koskinen, K. T. (2018). Collaborative systems and environments for future working life: Towards the integration of workers, systems and manufacturing environments. In The impact of digitalization in the workplace (pp. 25-38). Springer, Cham. https://doi.org/10.1007/978-3-319-63257-5_3

[58] Saunila, M., Ukko, J., \& Rantala, T. (2019). Value co-creation through digital service capabilities: the role of human factors. Information Technology \& People. https://doi.org/10.1108//TP-10-2016-0224

[59] Taipale-Erävala, K., Lampela, H., \& Heilmann, P. (2015). Survival skills in SMEs - continuous competence renewing and opportunity scanning. Journal of East-West Business, 21(1), 1-21. https://doi.org/10.1080/10669868.2014.959232

[60] Lehner, F. (2018). ICT skills and competencies for SMEs: results from a structured literature analysis on the individual level. In The Impact of Digitalization in the Workplace (pp. 5569). Springer, Cham. https://doi.org/10.1007/978-3-319-63257-5_5

[61] Sousa, M. J. \& Wilks, D. (2018). Sustainable skills for the world of work in the digital age. Systems Research and Behavioral Science, 35(4), 399-405. https://doi.org/10.1002/sres.2540

[62] Gamache, S., Abdul-Nour, G., \& Baril, C. (2019). Development of a Digital Performance Assessment Model for Quebec Manufacturing SMEs. Procedia Manufacturing, 38, 1085-1094. https://doi.org/10.1016/j.promfg.2020.01.196

[63] Abel, J. \& Wagner, P. S. (2017). Industrie 4.0: Mitarbeiterqualifizierung in KMU. wt-Werkstattstechnik online, Jg, 107, 134-140.

[64] Hartmann, F. \& Berndt, M. (2019). Digitalisierung: Welche Kompetenzen werden gebraucht? Mittelstand Digital Magazin, 11. Wissenschaft Praxis.

[65] Vieru, D., Bourdeau, S., Bernier, A., \& Yapo, S. (2015, January). Digital competence: A multi-dimensional conceptualization and a typology in an SME context. In 2015 $48^{\text {th }}$ Hawaii International Conference on System Sciences (pp. 4681-4690). IEEE. https://doi.org/10.1109/HICSS.2015.557

[66] Hubschmid-Vierheilig, E., Rohrer, M., \& Mitsakis, F. V. (2019). Digital competence and SMEs: review of the relevant literature. $20^{\text {th }}$ International Conference on Human Resource Development Research and Practice across Europe (UFHRD), Nottingham Business School, Nottingham Trent University.

\author{
Authors' contacts: \\ Maria Hulla, Dipl. Ing, BSc \\ Institute of Innovation and Industrial Management, \\ Kopernikusgasse 24, $8010 \mathrm{Graz}$, Austria \\ +43 316873 7095, maria.hulla@tugraz.at \\ Christian Ramsauer, Univ. Prof. Dr. Techn. Dipl. Ing. \\ Institute of Innovation and Industrial Management, \\ Kopernikusgasse 24, 8010 Graz, Austria \\ +43 316873 7091, iim@tugraz.at
}

